DOI: https://doi.org/10.47405/mjssh.v5i12.585

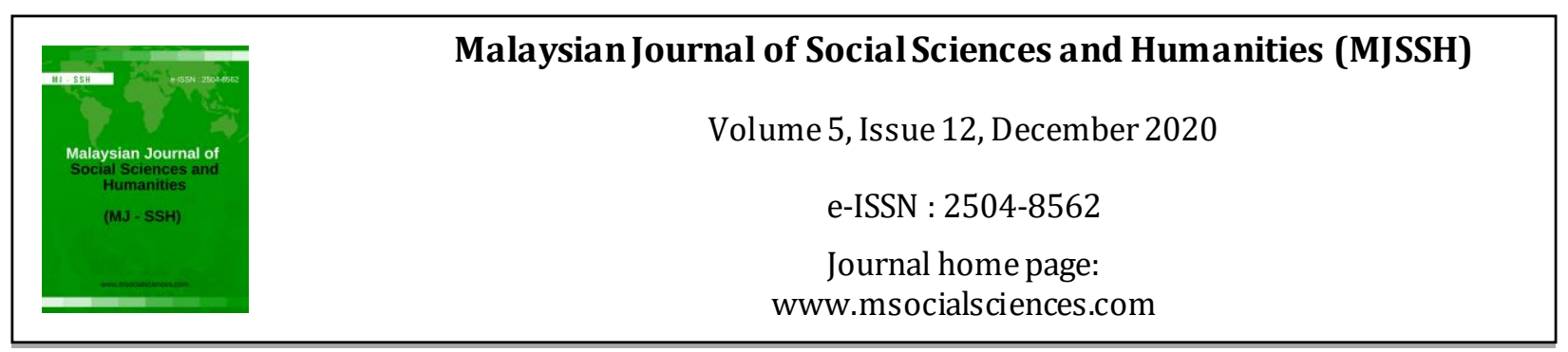

\title{
Majlis Gerakan Negara (MAGERAN): Usaha Memulihkan Semula Keamanan Negara Malaysia
}

\author{
Mohd Sohaimi Esa', Romzi Ationg1 \\ ${ }^{1}$ Pusat Penataran Ilmu dan Bahasa, Universiti Malaysia Sabah (UMS) \\ Correspondence: Mohd Sohaimi Esa (msohaimi@ums.edu.my)
}

\begin{abstract}
Abstrak
Susulan peristiwa 13 Mei 1969, sehari kemudian kerajaan telah mengisytiharkan Darurat di seluruh negara. Sehubungan itu, bagi memulihkan keamanan, kerajaan telah menubuhkan Majlis Gerakan Negara (MAGERAN) pada 16 Mei 1969. Pada umumnya, keanggotaan jawatankuasa dan matlamat MAGERAN telah banyak dibincangkan dalam mana-mana penulisan. Namun begitu, persoalan bagaimanakah pemimpin utama dalam MAGERAN dipilih masih belum begitu jelas dibincangkan lagi. Justeru itu, dengan berasaskan kaedah disiplin sejarah perkara ini akan dirungkaikan dalam artikel ini. Artikel ini juga akan membincangkan langkah-langkah yang telah diambil oleh MAGERAN untuk memulihkan semula keamanan dan sistem demokrasi yang telah lama diamalkan di negara ini. Dalam pada itu, kertas kerja ini menegaskan bahawa dengan adanya kepimpinan yang berwibawa dalam MAGERAN maka keamanan negara telah berjaya dipulihkan dalam masa yang singkat.
\end{abstract}

Kata Kunci: MAGERAN, Tunku Abdul Rahman, Tun Razak, darurat

\section{MAGERAN: An Effort to Restore Peace in Malaysia}

\begin{abstract}
In the wake of 13 Mei 1969 incident, that is a day after, the government of Malaysia have decided to declare a national emergency. In accordance, to restore peace, on 16 May 1996 the government established the 'Majlis Gerakan Negara (MAGERAN)'. The membership as well as the objective of MAGERAN, in general, thus has been widely discussed in numbers of writing. Despite that, however, the question of how exactly the MAGERAN key leaders been chosen remains unclear. Based on discipline of historic study, this study examines such questions. It also presents a discussion on what exactly were the steps applied by MAGERAN to restore not only national peace, but also democratic system traditionally used in this country. Thus, this paper argued that the presence of good leadership within MAGERAN has led to the restoration of national peace in a short period of time in this country.
\end{abstract}

Keywords: MAGERAN, Tunku Abdul Rahman, Tun Razak, emergency 


\section{Pendahuluan}

Rentetan daripada peristiwa 13 Mei 1969, Duli Yang Maha Mulia Seri Paduka Baginda Yang Dipertuan Agung pada 14 Mei 1969 telah mengisytiharkan Darurat di seluruh negara selaras dengan peruntukan Fasa 2 Perkara 150 Perlembagaan Persekutuan, yang bertujuan "untuk menjamin keselamatan negara dan juga untuk mengekalkan keamanan" (Jerome, 1970; The Straits Times, 15 Mei 1969; Leon Comber, 1981; Tunku Abdul Rahman, 1969; The National Operations Council, 1969; Romzi, Mohd. Sohaimi \& Mohd. Azri, 2020; Romzi, Mohd Azri, Mohd. Sohaimi \& Madiyem, 2020). Serentak itu juga kedudukan perlembagaan negara, Parlimen dan semua Majlis Undangan Negeri adalah digantung (Shaw, 1976). Pada dasarnya, sejak merdeka tidak pernah berlaku peristiwa seperti ini, tetapi kerajaan di bawah pimpinan Tunku Abdul Rahman-Tun Razak terpaksa melalui liku-liku yang dianggap sebagai titik hitam dalam sejarah negara. Susulan perisytiharan Darurat, Majlis Gerakan Negara (MAGERAN) telah ditubuhkan pada 16 Mei 1969. MAGERAN secara dasarnya berfungsi untuk mengawal ketenteraman, memastikan kelicinan pentadbiran negara dan mengawal keadaan harmoni serta saling mempercayai di kalangan rakyat pelbagai kaum. Dua permasalahan utama yang perlu diselesaikan oleh MAGERAN ialah masalah perpaduan kaum dan ketidakseimbangan ekonomi antara kaum. Justeru itu, kertas kerja ini akan membincangkan penubuhan Jawatankuasa MAGERAN dan langkah-langkah yang diambil dalam usaha memulihkan semula keamanan negara sejajar dengan peranan dan fungsinya.

\section{Penubuhan MAGERAN}

Pada 16 Mei 1969, kerajaan telah menubuhkan MAGERAN (Majlis Gerakan Negara/The National Operations Council). Penubuhan MAGERAN adalah usaha kerajaan dalam menangani masalah hubungan kaum akibat tragedi berdarah peristiwa 13 Mei 1969. Susulan perisytiharan Darurat, kerajaan terpaksa membentuk sebuah majlis atau badan sementara yang boleh menguruskan pentadbiran negara. MAGERAN telah diberi kuasa sepenuhnya untuk mentadbir negara yang mencontohi badan sepertimana semasa zaman Darurat (Jerome, 1970; The Straits Times, 15 Mei 1969; Comber, 1981; Tunku Abdul Rahman, 1969).

Jawatankuasa MAGERAN dipilih daripada wakil-wakil pemimpin pelbagai kaum negara ini. Namun begitu, majoriti mereka ialah pemimpin Melayu, yakni seramai enam orang, manakala dua orang lagi pemimpin bukan Melayu. Pemimpin Melayu terdiri daripada Tun Dr. Ismail bin Dato’ Abdul Rahman (Menteri Dalam Negeri), Datuk Hamzah bin Abu Samah (Menteri Penerangan dan Penyiaran), Tan Sri Ghazali Shafie (Setiausaha Tetap, Kementerian Luar Negeri), Tan Sri Abdul Kadir Shamsuddin (Pengarah Perkhidmatan Awam), Jeneral Tunku Osman Jiwa (Ketua Turus Angkatan Tentera) dan Tan Sri Mohammad Salleh (Ketua Polis Negara). Leftenan Jeneral Dato' Ibrahim Ismail dilantik sebagai Ketua Pegawai Eksekutif (CEO) MAGERAN. Sementara dua orang anggota pemimpin bukan Melayu adalah Tun Tan Siew Sin, Yang Dipertua MCA dan V.T. Sambanthan, Yang Dipertua MIC (Leon Comber, 1981). Jelaslah, jawatankuasa MAGERAN bukan sahaja terdiri daripada pemimpin politik, tetapi juga pemimpin utama dalam sektor perkhidmatan dan pertahanan. Mereka juga adalah nama-nama besar dalam barisan kepimpinan negara. Malah mereka dipilih oleh kerajaan kerana kemampuan dan kewibawaan para pemimpin tersebut untuk menangani isu-isu negara yang berlaku ketika itu. Sementara Tun Razak pula, selaku Timbalan Perdana Menteri ketika itu telah dilantik sebagai Pengarah MAGERAN. Menurut Tunku Abdul Rahman, pelantikan Tun Razak berasaskan pengalamannya sepertimana berikut:

"He was the right man, younger and more active, full of vim and vigour, and better suited to the arduour task of restoring the country to normalcy in view of his vast experience in handling the portfolios of both Defence and National Development" (Tunku Abdul Rahman, 1969, hlm. 100)

Selain pengalaman Tun Razak, Tunku yang menolak jawatan ini juga dikaitkan dengan masalah kesihatannya sendiri, yakni mengidap penyakit glaukoma dan penyakit lain. Semasa dilantik, Tun Razak berumur 47 tahun berbanding dengan Tunku Abdul Rahman yang berusia 66 tahun (Ooi, 2007). 
Pada dasarnya, sebagai Pengarah MAGERAN, Tun Razak mempunyai kuasa eksekutif yang hampir tiada batasannya. Beliau dibenarkan untuk membuat keputusan sendiri mengenai pemerintahan dan pentadbiran negara selari dengan perisytiharan Darurat tersebut. Dengan erti kata lain, "diktator" merupakan istilah yang paling tepat untuk dirinya, sungguhpun beliau bimbang dengan kuasa yang dimilikinya (Shaw, 1976). Dari sudut lain, hal ini menarik perhatian dalam kalangan ahli-ahli politik mahupun para akademik untuk menilai diktator Tun Razak sepanjang menerajui MAGERAN.

Sebagai contohnya, pada pengamatan Ooi (2007), "Tun Razak could virtually (have become) a dictator at that time, but he never used his power in that direction. Next to him was Doc Ismail" (2007, hlm. 223). Noordin Sopiee secara agak dramatik merakamkan, bahawa "Tun barang kali bekerja lebih keras daripada mana-mana diktator dalam sejarah untuk menyingkirkan kuasa diktator dari tangannya sendiri dan berusaha menjauhinya" (The Straits Times, 15 Januari 1976). Wahab Majib pula berpendapat bahawa, "gagasan 'diktator yang baik hati' pernah bermain di fikiran Tun Razak, namun dilupakan akibat desakan bertali-arus oleh Tun Dr. Ismail supaya parlimen dipulihkan secepat mungkin (Ooi, 2007). Berdasarkan kenyataan-kenyataan tersebut, Tun Razak sebagai Pengarah MAGERAN dilihat berusaha untuk mengelakkan diri daripada menggunakan sewenang-wenangnya kuasa yang ada pada dirinya. Malah Tun Dr. Ismail dikatakan menjadi 'tadbir' kepada Tun Razak sepanjang menjalankan tugas sebagai Pengarah MAGERAN.

Bagi Tun Razak, beliau sendiri sentiasa berhati-hati dalam menunaikan tanggungjawab yang diamanahkan kepadanya. Menurutnya:

“...sekiranya tuan-tuan mahu berkhidmat kepada rakyat, kuasa yang berlebihan adalah merbahaya. Kerana kalaupun tuan-tuan tidak bercadang hendak menyalahgunakan kuasa itu, tuan-tuan mungkin secara tidak sengaja berbuat demikian, terutama apabila tanggungjawab itu dibahagi-bahagikan kepada orang lain. Tuan-tuan tidak dapat mengawal semuanya sendiri. Tuan-tuan sendiri boleh jadi ikhlas, tetapi dapatkah ditentukan semua pegawai-pegawai bertugas atas nama kita sebenarnya ikhlas? Mengikut sistem demokratik, kita mempunyai Parlimen dan Majlis Undangan Negeri yang boleh menyekat gerak-geri kita. Selain daripada itu ada pula parti-parti pembangkang yang akan membentangkan kepada ramai sekiranya terdapat kesilapan-kesilapan. Tetapi yang paling penting ialah tiap tiap beberapa tahun sekali kita akan menghadapi pengundi-pengundi dan mereka akan menyalahkan kita segala kesalahan kita" (Ooi, 2007, hlm. 190).

Berdasarkan petikan di atas, jelas menggambarkan falsafah dan perjuangan politik Tun Razak. Beliau berpendapat bahawa kuasa pemerintahan yang bersifat diktator perlu dijauhi dalam usaha untuk menjamin kesejahteraan rakyat dan negara. Sebaliknya, beliau lebih percaya dengan sistem demokrasi berparlimen sepertimana yang menjadi amalan negara ini. Sistem politik ini didapati begitu serasi dengan kehendak rakyat negara ini yang terdiri daripada pelbagai kaum, budaya dan agama.

Pada 19 Mei 1969, mesyuarat kali pertama MAGERAN diadakan dengan dipengerusikan oleh Tun Razak (The Straits Times, 20 Mei 1969). Situasi mesyuarat MAGERAN antara lain dapat digambarkan sepertimana berikut:

"Mesyuarat Mageran setiap hari berlangsung tanpa banyak perbahasan, manakala "ahli daripada pihak tentera dan polis memberi pandangan tentang apa yang berlaku dan kadang kala menyatakan keperluan mereka." Pendirian Ismail "kerap ditanyakan, dan semua orang termasuk Timbalan Perdana Menteri, menuruti pendapatnya" (von Vorys, 1976: 346). Abdul Rahman Hamidon, Setiausaha Mageran yang pertama, kagum melihat rasa saling hormat yang ketara antara Razak dengan Ismail. Katanya, dalam banyak perkara dia dihantar oleh Razak untuk meminta pendapat Ismail, dan kepada mereka yang bekerja di bawahnya Razak menegaskan itulah cara mereka bekerja (AR Hamidon, wawancara 09/09/2005). Abdullah Badawi, ... Katanya Razak mempengerusikan kebanyakan mesyuarat, dan Ismail menjadi timbalan tidak rasmi. Razak selalu 
menoleh kepada Ismail untuk mendapat isyarat apabila sesuatu perkara baru ditimbulkan, dan jika Ismail mengambil haluan pemikiran yang bercanggahan dengan apa yang Razak katakan pada mulanya, mesyuarat menjadi lebih panjang dan Razak nanti cuba menerapkan pendapat Ismail. Mereka berdua tidak pernah dilihat berbeza pendapat di hadapan umum" (Abdullah Badawi, wawancara 14/05/2006 Dlm. Ooi, 2007, hlm. 191).

Sementara itu, Tunku Abdul Rahman pula membentuk Jemaah Menteri Darurat pada 20 Mei 1969. Tunku Abdul Rahman terus mengekalkan jawatannya sebagai Perdana Menteri. Sementara Tun Razak pula terus dikekalkan sebagai Timbalan Perdana Menteri dan Menteri Pertahanan, di samping diberi jawatan baru iaitu Pemangku Menteri Kewangan (Leon, 1981). Sementara Menteri Keselamatan Dalam Negeri pula disandang oleh Tun Dr. Ismail bin Dato' Abdul Rahman yang secara sukarela berkhidmat kembali bagi membantu mengurangkan bebanan Tun Razak. Tun Razak sendiri yang meminta Tun Dr. Ismail untuk menerajui kementerian ini sungguhpun dirinya uzur. Sememangnya jelas Tun Razak mempercayai Tun Dr. Ismail (Ooi, 2007) yang menggambarkan juga sebagaimana kepercayaan Tunku Abdul Rahman terhadap dirinya sendiri. Sungguhpun tidak menyandang Menteri Hal Ehwal Dalam Negeri, Tun Razak masih tidak dapat lari daripada usaha untuk meleraikan masalah yang berlaku dalam negara, khususnya dampak tragedi 13 Mei itu. Malah Tun Razak, selaku Pengarah MAGERAN begitu serasi dengan Tun Dr. Ismail yang mengambil alih jawatan tersebut. Tun Dr. Ismail juga merupakan salah seorang anggota MAGERAN.

Walau bagaimanapun, terdapat suara sumbang dengan pembentukan Kabinet baru itu, khususnya apabila tawaran pembangkang untuk bekerjasama ditolak oleh kerajaan (Ooi, 2007). Tun Razak membidas dengan menegaskan bahawa dirinya tidak pernah berniat untuk membentuk kabinet yang sepenuhnya dianggotai orang Melayu. Hal ini terbukti dengan penyertaan MCA dalam kabinet baru tersebut. Di samping itu, Tun Razak turut menjelaskan bahawa hubungan Kabinet dengan MAGERAN sama seperti hubungan antara kabinet dengan majlis yang sama namanya pada zaman Darurat dahulu. Menurutnya, "[MAGERAN] tidak akan mengatasi Kabinet, tetapi pengarah gerakan negara akan mempunyai kuasa jauh melebihi menteri (Ooi, 2007).

Semasa sidang akhbar lain, Tunku Abdul Rahman pula dengan tegas masih menganggap dirinya masih lagi berkuasa dalam hal ehwal pentadbiran negara (The Straits Times, 17 dan 20 Mei 1969), walaupun pada dasarnya ia telah diletakkan di bawah tanggungjawab MAGERAN. Dengan erti kata lain, Tun Razak masih perlu bertindak atas nasihat Tunku Abdul Rahman sebagai Perdana Menteri. Pada pemahaman umum ketika itu pula, Tunku telah hilang kewibawaan di dalam parti dan dalam kalangan orang Melayu, dan tidak mampu mengelolakan krisis lagi. Malah bukan sahaja orang tempatan, tetapi persepsi yang sama turut terdapat dalam kalangan masyarakat asing dan media antarabangsa (Ooi, 2007). Apapun didapati Tun Razak selaku Pengarah MAGERAN tidak pernah menjadikan isu ini sebagai halangan, malah terus saling berganding bahu dengan Tunku Abdul Rahman dalam usaha meleraikan kemelut perkauman tersebut (Shaw, 1976; Mohd. Sohaimi, 2011).

\section{MAGERAN: Usaha ke Arah Memulihkan Semula Keamanan Negara}

MAGERAN telah diamanahkan untuk mengembalikan semula keamanan negara dan menjamin kesejahteraan rakyat. Di samping itu, majlis ini bertanggungjawab untuk memastikan pentadbiran negara dapat berjalan dengan lancar dan sempurna berikutan dengan penggantungan sementara Parlimen dan semua Majlis Undangan Negeri. Selain di peringkat pusat, MAGERAN di peringkat Negeri dan Daerah juga ditubuhkan untuk melicinkan lagi urusan pentadbiran negara. Dengan cara ini, majlis ini dapat mengatur suatu pemerintahan secara ketenteraan yang boleh melaksanakan segera keputusan yang diarahnya tanpa perlu kepada perundingan sepertimana amalan dalam pemerintahan secara demokrasi (Shaw, 1976; Mohd. Sohaimi et al., 2020).

Antara langkah terawal MAGERAN adalah menggantung serta merta pilihan raya di Sabah dan Sarawak (Ong, 2005) serta menghentikan penerbitan semua akhbar di Malaysia (Ooi, 2007). Langkah juga diambil untuk mengatasi masalah bekalan makanan selepas berlakunya tragedi 13 Mei, 
terutamanya sekitar Kuala Lumpur dan negeri Selangor (Shaw, 1976). Dari segi keselamatan pula, MAGERAN telah bekerjasama dengan pasukan polis untuk mendapatkan maklumat perisikan, serta melakukan tindakan dari segi kawalan dan serbuan ke atas kumpulan subversif bagi menjamin keselamatan dalam negeri. Semua langkah yang diambil ini dapatlah dianggap sebagai usaha bersepadu MAGERAN untuk membendung seberapa segera masalah hubungan kaum yang tercetus akibat tragedi 13 Mei itu.

Menjelang hujung minggu pertama, keadaan sudah mulai tenteram hingga perintah berkurung dapat digantung di kebanyakan kawasan. Majlis ini mengumumkan 15 surat khabar dibenarkan untuk diterbitkan semula di bawah kawalan MAGERAN. Pas perintah berkurung untuk wartawan dibatalkan bagi tempoh yang tidak ditentukan, dan dari itu berita krisis hanya datang secara rasmi dari Pusat Penyelarasan Penerangan, MAGERAN (Ooi, 2007). Penghujung bulan Mei pula, angka rasmi daripada MAGERAN menunjukkan 177 terbunuh, 340 tercedera, 136 buah rumah terbakar dan 119 buah kenderaan mengalami kerosakan. Di Singapura juga berlaku keganasan kecil, tetapi masih berada dalam keadaan yang terkawal. Pada bulan-bulan seterusnya, bilangan angka rasmi tidak banyak meningkat. Sehingga 31 Julai, 196 orang terbunuh dan 439 tercedera, 180 daripadanya memiliki senjata api, 9,143 orang diberkas dan dituduh di mahkamah (Ooi, 2007).

Selang sebulan Tun Razak mengetuai MAGERAN, beliau sementara waktu terpaksa mengalihkan perhatiannya daripada hal-ehwal dalam negeri kepada isu dalaman partinya, UMNO. Hal ini berlaku apabila wujud perselisihan personaliti (Shaw, 1976) di antara Dr. Mahathir Mohammad dengan Yang Dipertua UMNO, Tunku Abdul Rahman. Dr. Mahathir telah melemparkan kecaman secara peribadi ke atas Tunku Abdul Rahman. Sementara Tun Razak turut menerima tempiasnya apabila terdapatnya khabar angin yang menuduh beliau turut bersekongkol dengan golongan yang menentang Tunku Abdul Rahman. Khabar angin tersebut dinafikan dengan keras oleh Tun Razak, mahupun Tunku Abdul Rahman (Tunku Abdul Rahman, 1969; Ooi, 2007). Sebaliknya, Tunku meminta Tun Razak menyelesaikan isu tersebut demi menjamin keutuhan UMNO. Sebagai Timbalan Presiden UMNO, Tun Razak telah membincangkan isu tersebut bersama-sama dengan ahli Majlis Tertinggi UMNO pada 12 Julai. Walaupun Tunku Abdul Rahman tidak menghadirinya, tetapi Dr. Mahathir telah hadir untuk menyatakan pendiriannya itu. Bagi mengelakkan perselisihan itu berpanjangan, Dr. Mahathir bersedia untuk meletakkan jawatannya sebagai ahli Majlis Tertinggi UMNO (Yayasan Tun Razak, 2005; Milne \& Mauzy, 1982). Beliau bersara sementara dalam politik, tetapi muncul semula beberapa tahun kemudiannya untuk berkhidmat di bawah Tun Razak sebagai salah seorang Menteri Kabinetnya (Shaw, 1976).

Pada 9 Oktober 1969, MAGERAN menerbitkan Laporan berkaitan dengan tragedi 13 Mei. Laporan ini dapat dianggap sebagai laporan rasmi kerajaan tentang kejadian tersebut. Bagi Tun Razak sebagai Pengarah MAGERAN menganggap bahawa, “... B Mei 1969 akan tercatit dalam sejarah sebagai hari tragedi nasional" (Majlis Gerakan Negara, 1969; Comber, 1981). Berdasarkan laporan MAGERAN, punca tercetusnya rusuhan ini dikaitkan dengan tindak-tanduk pihak tertentu sama ada Perikatan, mahupun parti-parti pembangkang yang menimbulkan isu-isu sensitif sehingga menyemarakkan api perkauman. Masalah ini bertambah rumit lagi apabila DAP dan Gerakan menganjurkan 'perarakan kemenangan' di Kuala Lumpur. Penganjuran perarakan tersebut dianggap sebagai faktor serta-merta tercetusnya tragedi 13 Mei. Kerajaan pada ketika itu pula gagal untuk menghalang beberapa kejadian yang boleh menggugat keselamatan negara. Antaranya termasuklah kejadian pembunuhan yang berlaku di Pulau Pinang dan Kuala Lumpur sebelum menjelangnya pilihan raya. Begitu juga, tiada langkah tegas yang diambil oleh kerajaan untuk menghalang penganjuran perarakan oleh DAP dan Gerakan selepas pengumuman pilihan raya. Hal ini memperlihatkan kelemahan kerajaan yang ketika itu tidak menduga sama sekali boleh berlaku tragedi tersebut.

MAGERAN mengakui bahawa terdapat perbezaan tafsiran terhadap perlembagaan antara orang Melayu dan bukan Melayu menjadi punca tercetusnya tragedi 13 Mei. Pada umumnya, orang bukan Melayu kurang senang dengan kedudukan istimewa orang Melayu dalam perlembagaan. Mereka juga tidak berpuas hati apabila orang Melayu menguasai politik dan pemerintahan negara. Sementara orang Melayu pula tidak puas hati apabila mereka masih ketinggalan dalam bidang ekonomi dan sosial berbanding dengan bukan Melayu, khususnya dengan orang Cina. Masalah yang berakar umbi sejak 
sebelum merdeka itu terus membelenggu sejarah hubungan kaum di negara ini (Means, 1970; Romzi, et al., 2018; Mohd. Sohaimi et al., 2020). Natijahnya, kerajaan masih belum dapat mencari jalan untuk membina perpaduan yang sebenar. Dasar-dasar yang diperkenalkan oleh kerajaan pula masih lagi mempunyai kelemahan dan kepincangan dalam usaha membina negara bangsa Malaysia.

Walaupun terdapat usaha-usaha yang dilakukan oleh kerajaan, namun begitu hasilnya belum begitu jelas dalam mengubah kedudukan sosio-ekonomi orang Melayu. Jurang kadar kemiskinan antara orang Melayu dengan bukan Melayu masih lagi ketara. Pada tahun 1970, kadar kemiskinan dalam kalangan orang Melayu jauh lebih tinggi iaitu 64.8 peratus berbanding dengan kaum Cina (26 peratus) dan India (39.2 peratus) (Kevin, et al., 1980). Sementara purata pendapatan keluarga sebulan dalam kalangan orang Melayu pula hanya RM172.00 iaitu dua kali ganda jauh lebih rendah berbanding dengan kedua-dua kaum iaitu Cina (RM394.00 ) dan India (RM304.00) . Natijahnya, MAGERAN merumuskan bahawa ketidakseimbangan itu sebagai tanda ketidakpercayaan antara orang Melayu dengan Cina adalah seperti duri dalam daging dalam sejarah negara sekarang.

Sungguhpun begitu, MAGERAN mengakui bahawa tragedi 13 Mei telah menggerakkan semua kaum untuk mengambil langkah tertentu bagi mewujudkan keharmonian dan keadilan sosial. Antara langkah diambil adalah dengan menubuhkan Jabatan Perpaduan Negara dan Majlis Perundingan Negara pada Januari 1970. Kedua-dua badan ini mempunyai hubungan secara langsung dengan MAGERAN. Semasa mengemukakan laporan, Tun Razak selaku Pengarah MAGERAN telah “...menjemput wakilwakil daripada pelbagai kumpulan di negara ini - golongan agama, politik, ekonomi dan lain-lain untuk berkhidmat dalam Majlis Perundingan Negara." Untuk majlis ini, Tun Razak telah memilih seramai 66 orang dalam kalangan pemimpin pelbagai pertubuhan sebagai ganti kepada parlimen yang sementara waktu terpaksa digantung ketika itu. Objektif majlis ini adalah untuk membincangkan langkah-langkah ke arah mewujudkan perpaduan dan keharmonian antara kaum agar tragedi 13 Mei tidak berulang kembali. Di samping itu, ia dilakukan untuk persediaan bagi mengembalikan semula sistem demokrasi berparlimen di negara ini. Bagi Tun Razak, sesuatu kuasa itu mestilah disertai dengan prinsip 'check and balance' untuk melahirkan kepimpinan yang berkesan (Majlis Gerakan Negara, 1969; Means, 1970).

Menjelang hari ulang tahun pertama rusuhan kaum 13 Mei, MAGERAN telah mengambil langkah berjaga-jaga dengan mengarahkan bahagian keselamatan dan angkatan tentera untuk mengambil tindakan bagi mengelakkan kekacauan tercetus semula. Secara relatifnya, keadaan negara boleh dikatakan bertambah baik dan keamanan dapat dipulihkan sepenuhnya. Sebagai usaha memulihkan semula sistem demokrasi berparlimen, kerajaan telah memutuskan untuk mengadakan semula pilihan raya di Sabah dan Sarawak. Pilihan raya di kedua-dua negeri ini begitu penting kepada kerajaan kerana lebih dua pertiga kerusi parlimen diperlukan oleh Perikatan susulan kehilangan banyak kerusi dalam pilihan raya 1969. Selain itu, suara majoriti itu penting untuk memelihara dan mendapatkan sokongan hal yang berkaitan dengan perlembagaan dan reformasi ekonomi yang dirancang oleh kerajaan Perikatan. Malah sesetengah pemimpin Perikatan menganggap sekiranya gagal mendapatkan majoriti, maka demokrasi berparlimen tidak mungkin dapat diwujudkan kembali.

Sebagai langkah berjaga-jaga, kerajaan telah memperketat tatatertib semasa berkempen dalam usaha membendung permusuhan antara kaum. Di Sabah, pilihan raya disambung semula pada 21-27 Jun 1970. Sebelum pilihan raya ditangguhkan tahun 1969, USNO telah pun menguasai 10 kerusi parlimen, sementara enam kerusi yang dipertandingkan pilihan raya kali ini berjaya dimenangi oleh USNO dengan tiga kerusi lagi dan Persatuan Cina Sabah (SCA) pula tiga kerusi. Walaupun berita ini baik untuk Tun Razak selaku Pengarah MAGERAN dan Perikatan, tetapi untuk mendapatkan majoriti Perikatan memerlukan sekurang-kurangnya 14 kerusi lagi yang tentunya bergantung kepada keputusan pilihan raya di Sarawak.

Di Sarawak pula, pengundian telah dimulakan pada 6 Jun dan 4 Julai barulah diumumkan keputusannya. Semasa pengumuman, di Kuching sebagai persediaan untuk menghadapi segala kemungkinan daripada keputusan pilihan raya tersebut. Berdasarkan keputusan, sebanyak 24 kerusi yang dipertandingkan dengan pecahan kemenangan iaitu Parti Bumiputera (5), Persatuan Cina Sarawak - SCA (2), PESAKA (3), SUPP (5) dan SNAP (9) (Milne \& Ratnam, 1974). Perikatan 
Sarawak yang terdiri daripada Parti Bumiputera, SCA dan PESAKA hanya memenangi 10 daripada 24 kerusi. Jelas keputusan ini masih belum dapat memenuhi hasrat Perikatan yang memerlukan suara majoriti, yakni sekurang-kurangnya empat kerusi lagi yang diperlukan daripada jumlah dua pertiga kerusi. Susulan itu, Tun Razak sebagai Pengarah MAGERAN telah menemui pemimpin SUPP, Ong Kee Hui (Michael B. Leigh, 1974; Milne \& Ratnam, 1974; Milne \& Mauzy, 1982). Ong (2005) mengulas dalam hal ini sebagaimana berikut:

“Apa yang terjadi adalah seperti touch and go. Tun Razak terpaksa menggunakan kemahiran 'memujuknya' untuk mendapatkan sokongan SUPP. Kejayaan tersebut telah memulihkan semula demokrasi berparlimen" (Ong Kee Hui, 2005, hlm. 243; Maurice Baker, 2006, hlm. 22).

Langkah yang dilakukan oleh Tun Razak itu telah berjaya untuk melepasi halangan bagi mendapatkan sokongan majoriti (Milne \& Mauzy, 1982). Sementara SNAP pula terus kekal sebagai parti pembangkang, tetapi semasa berunding dengan Tun Razak pemimpin SNAP telah berikrar tidak akan membangkang sebarang dasar kerajaan pusat (Ong, 2005). Jelaslah pencapaian Tun Razak itu dapatlah dianggap sebagai suatu kejayaan besar dalam karier politiknya apatah lagi selepas tragedi 13 Mei. Hal ini bukan sahaja untuk dirinya sahaja, tetapi juga di pihak MAGERAN dan Perikatan.

Selepas Sabah dan Sarawak, Tun Razak selaku pengarah MAGERAN berusaha pula menyelesaikan masalah dengan kerajaan Selangor dan Perak. Tugas beliau bertambah mudah apabila terdapatnya calon pembangkang yang melompat parti dengan menyokong Perikatan. Di Perak, tiga orang ahli pembangkang Majlis Undangan Negeri (dua daripada PPP dan seorang daripada DAP) telah menyertai Perikatan. Dengan itu, Perikatan berjaya mendapat suara majoriti apabila menguasai 22 daripada 18 kerusi. Sementara di Selangor pula, hal yang sama berlaku apabila seorang ahli Majlis Undangan Negeri dari Gerakan Rakyat dan seorang ahli bebas telah menyebelahi Perikatan untuk memastikan Perikatan menguasai kerajaan negeri dengan kelebihan 16 berbanding 12 kerusi (Shaw, 1976). Sesungguhnya, pembentukan kerajaan negeri dari Perikatan itu menandakan Tun Razak dan MAGERAN telah berjaya meleraikan sebahagian besar kemelut politik perkauman, khususnya di Perak dan Selangor dan amnya Malaysia.

Pada bulan Ogos 1970, MAGERAN dengan persetujuan Majlis Perundingan Negara secara arbitrari telah memerintahkan untuk dikuatkuasakan Akta Hasutan. Akta ini memperuntukkan bahawa menjadi suatu kesalahan kepada sesiapa sahaja yang mempersoalkan secara terbuka isu-isu sensitif yang terkandung dalam perlembagaan negara. Isu-isu sensitif yang dimaksudkan termasuklah berkaitan dengan kuasa dan keistimewaan Yang Dipertuan Agong atau Raja-raja Melayu, kewarganegaraan, Bahasa Melayu sebagai bahasa rasmi, kedudukan istimewa orang Melayu dan Islam sebagai agama persekutuan. Akta ini dikuatkuasakan sebagai langkah untuk membendung pertikaian isu sensitif tersebut, di samping untuk mengelakkan kejadian yang tidak diingini sepertimana tragedi 13 Mei 1969.

Sempena Hari Kebangsaan ke-13, 31 Ogos 1970, MAGERAN memfokuskan perayaan ke arah memupuk perasaan muhibah antara kaum dan cintakan negara dalam kalangan rakyat. Ruku negara merupakan antara usaha terpenting MAGERAN untuk mencapai matlamat tersebut. Lima prinsip Ruku negara itu meliputi keperluan kebendaan (material) dan kerohanian (spiritual) telah dilancarkan oleh Yang Dipertuan Agung (Means, 1970). Bagi Tun Razak, Ruku negara dapat ditakrifkan kepentingannya sepertimana berikut:

“...bolehlah dianggap sebagai piagam rakyat atau people's charter yang menentukan haluan rakyat Malaysia untuk tahun-tahun akan datang. Saya percaya vision masyarakat hari depan seperti yang dibayangkan dalam Rukunnegara iaitu satu masyarakat yang moden dan progresif - dengan sepenuh-penuh erti kata bukan hanya diterima begitu saja tetapi menjadi inspirasi setiap rakyat untuk berusaha mencapainya" (Ucapan Perdana Menteri di pembukaan Seminar Rukunegara, di Sekolah Menengah Perempuan Methodist, Kuala Lumpur pada 
$20 h$ b Ogos, 1971", Ucapan-ucapan Tun Haji Abdul Razak 1971, Arkib Negara Malaysia dan Jabatan Perdana Menteri, Kuala Lumpur, 1976, hlm. 365)

Sempena ulang tahun kemerdekaan, MAGERAN turut mengisytiharkan tamatnya perintah berkurung di beberapa kawasan negara ini. MAGERAN menarik balik pengharaman semua aktiviti politik yang sebelumnya telah digantung sementara waktu ekoran tragedi 13 Mei 1969. Sementara beberapa orang tahanan politik termasuk Lim Kit Siang (pemimpin DAP) telah dibebaskan dari tahanan ISA. Peristiwa hitam yang menyelubungi para pemimpin MAGERAN semakin berjaya dipulihkan sepenuhnya. Liku-liku sebagai Timbalan Perdana Menteri dan Pengarah MAGERAN kini telah berada di penghujungnya apabila Tun Razak dilantik sebagai Perdana Menteri Malaysia kedua menggantikan Tunku Abdul Rahman pada 23 September 1970. Tun Razak telah membentuk kabinet baru dengan Tun Dr. Ismail Abdul Rahman sebagai Timbalan Perdana Menteri. Seterusnya, fungsi kerajaan berparlimen mula dipulihkan semula pada 23 Februari 1971.

\section{Kesimpulan}

MAGERAN ditubuhkan untuk memulihkan semula keamanan negara susulan tragedi 13 Mei 1969. Majlis ini yang diketuai oleh Tun Razak telah berjaya mengembalikan semula keamanan negara dan kepercayaan antara kaum. Jelaslah MAGERAN dipimpin oleh mereka yang berwibawa bukan sahaja dalam kalangan ahli politik pelbagai kaum, tetapi juga pemimpin awam. MAGERAN telah mengatur usaha yang boleh dianggap sebagai langkah serta merta seperti menjalankan pentadbiran negara susulan perisytiharan Darurat menubuhkan Majlis Perundingan Negara, Jabatan Perpaduan Negara, memperkenalkan Akta Hasutan, dan menyusun semula politik negara. Setelah itu, keadaan negara semakin aman sehinggalah Tun Razak dilantik sebagai Perdana Menteri menggantikan Tunku Abdul Rahman pada September 1970. Seterusnya, MAGERAN dibubarkan apabila kerajaan berparlimen dikembalikan semula pada 23 Februari 1971.

\section{Penghargaan}

Artikel ini pernah dibentang dalam 'The $2^{\text {nd }}$ International Conference on Society \& Religion, Centre for the Promotion of Knowledge and Language Learning, Universiti Malaysia Sabah, 27 August 2017 .

\section{Rujukan}

Baker, M. (2006). Negarawan Sepanjang Zaman. Kuala Lumpur: Lembaga Pemegang Amanah Yayasan Tun Razak.

Comber, L. (1981). 13 May 1969, A Survey of Sino-Malay Relations. Kuala Lumpur: Heinemann Asia Ltd.

Jerome, R. B. (1970). Malaysia: Continuity or Change? Asian Survey, 10(2), 152-160.

Majlis Gerakan Negara (1969). The May 13 Tragedy: A Report. Kuala Lumpur: Majlis Gerakan Negara.

Means, G. P. (1970). Malaysian Politics. Malaya: Hodder and Stoughton.

Michael B. L. (1974). The Rising Moon: Political Change in Sarawak. Sydney: Michael Leigh Publisher.

Milne, R. S. \& Ratnam, K. J (1974). Malaysia: New States in a New Nation. Milton Park, UK: Routledge Taylor \& Francis.

Milne, R.S. \& Mauzy, D.K. (1982). Politik dan Kerajaan di Malaysia. Kuala Lumpur: Dewan Bahasa dan Pustaka Kementerian Pelajaran Malaysia.

Mohd. Sohaimi Esa (2011). Sumbangan Tun Abdul Razak dalam membina hubungan MalaysiaIndonesia. Journal Jabatan Sejarah Universiti Malaya, 11, 397-216

Mohd. Sohaimi Esa, Romzi Ationg, Siti Aida Lokin, Sirahim Abdullah, Abang Mohd. Razif Abang Muiz \& Mohd. Azri Ibrahim (2020). Linking Leadership Ethics and Intergroup Relationship 
through the Revision of Leadership Theories and Intergroup Relationship. Solid State Technology, 63(6), 742-752.

Mohd. Sohaimi Esa, Romzi Ationg, Suraya Sintang, Abang Mohd. Razif Abang Muiz, Mohd Azri Ibrahim \& Sirahim Abdullah (2020). Youth Voluntary Organization, Leadership and Intergroup Relationship in Sabah, Malaysia: A Preliminary Discussion. Solid State Technology, 63(6), 722730 .

Ong, K. H. (2005). Enticing Sarawak (hlm. 207). Dlm. Yayasan Tun Razak (ed.), Tun Abdul Razak: A Personal Portrait. Kuala Lumpur: Utusan Pub. \& Distributors Sdn. Bhd.

Ooi, K. B. (2007). Bukan Kerana Pangkat: Tun Dr. Ismail Dan Masanya. Singapore: ISEAS \& Strategic Information Research Development.

Romzi Ationg, Azlan Gansau \& Andreas Totu. (2018). Ethnohistorical Analysis on the Resurgence of Multiracial Political Ideology through 'Sabah for Sabahan'Slogan in Sabah, Malaysia. ASEAN/Asian Academic Society International Conference Proceeding Series, 186-194

Romzi Ationg, Mohd Azri Ibrahim, Mohd. Sohaimi Esa \& Madiyem Layapan (2020). Analisis Pola Pengundian dan Senario Politik Semasa di Malaysia Era Pasca Pilihan Raya Umum (PRU) Ke-14 Berdasarkan Pilihan Raya Kecil P186 Sandakan, Sabah. Malaysian Journal of Social Sciences and Humanities (MJSSH), 5(5), 60-71.

Romzi Ationg, Mohd. Sohaimi Esa \& Mohd. Azri Ibrahim (2020). Menyingkap Polemik Peralihan Kuasa Secara Luar Biasa Mengikut Perspektif Demokrasi Berparlimen. Malaysian Journal of Social Sciences and Humanities (MJSSH), 5(11), 43-53.

Shaw, W. (1976). Tun Razak: His Life and Times. London, UK: Longman.

The National Operation Council (1969). The May 13 Tragedy: A Report. Kuala Lumpur: The National Operations Council.

The Straits Times, 15 Mei 1969.

The Straits Times, 17 Mei 1969.

The Straits Times, 20 Mei 1969.

The Straits Times, 20 Mei 1969.

Tunku Abdul Rahman (1969). May 13 Before and After. Kuala Lumpur: Utusan Melayu Press Ltd.

Yayasan Tun Razak (2005). Tun Abdul Razak: A Personal Portrait. Kuala Lumpur: Utusan Pub. \& Distributors Sdn. Bhd. 